\title{
The effect of tongue-tie application on stress responses in resting horses
}

Laura Marsh $^{1 *}$, Paul McGreevy ${ }^{2}$ Susan Hazel ${ }^{1}$, Luiz Santos ${ }^{1}$, Michelle Hebart ${ }^{1}$ and Samantha Franklin ${ }^{1}$

*Corresponding author: laura.latimer-marsh@,adelaide.edu.au

${ }^{1}$ The Equine Health and Performance Centre, School of Animal and Veterinary Sciences, University of Adelaide, Roseworthy Campus, SA5371, AUSTRALIA.

${ }^{2}$ Sydney School of Veterinary Science, University of Sydney, NSW 2006, AUSTRALIA

\section{Abstract}

2 Tongue-ties (TT) are commonly applied to both Standardbred and Thoroughbred racehorses to increase control, 3 by preventing them from getting their tongue over the bit, and as a conservative treatment for equine respiratory 4 conditions, principally dorsal displacement of the soft palate. This study investigated responses to TT application 5 in horses, at rest, using both behavioural (head-tossing, ear position, gaping and lip licking) and physiological 6 (salivary cortisol concentrations, eye surface temperature and heart rate) indices. Twelve Standardbred horses (six 7 of which were naïve to TT) were used in a randomised crossover design. The study comprised 3 phases; Phase 1 8 (Baseline), Phase 2 (Treatment), and Phase 3 (Recovery). At phase 2, tongue tie application (TTA) was performed 9 using a rubber band that was looped around the tongue and secured to the mandible for 20 minutes. The control 10 treatment (C) incorporated 30 secs of tongue manipulation, at the start of the $20 \mathrm{~min}$, however no TT was applied. 11 Behaviours (head- tossing, ear position, mouth gaping and lip-licking) and heart rate (HR) were recorded for the 12 duration of the study and analysed in ten minute intervals. Salivary samples were taken at the end of each phase 13 for subsequent cortisol assays and infrared thermography images were taken of each eye at 5-minute intervals. 14 Statistical analyses were performed in SPSS using linear mixed effects models and repeated measures general 15 linear models, to determine differences between treatments and within treatments, over time. Compared to control, 16 there was more head-tossing/shaking $(\mathrm{p}<0.001)$, gaping $(\mathrm{p}<0.001)$ and backwards ear position $(\mathrm{p}<0.001)$ and less 17 forward ear position $(\mathrm{p}<0.001)$ during TTA, in Phase 2. Horses with previous experience of TT showed more 18 head-tossing $(\mathrm{p}=0.040)$ and gaping $(\mathrm{p}=0.030)$ than naïve horses. Lip-licking was more frequent after TTA 19 treatment than control, during Phase $3(\mathrm{p}<0.001)$. Salivary cortisol concentrations increased after TTA $20(1846.1 \mathrm{pg} / \mathrm{mL} \pm 478.3 \mathrm{pg} / \mathrm{mL}$ vs $1253.6 \mathrm{pg} / \mathrm{mL} \pm 491.6 \mathrm{pg} / \mathrm{mL}, \mathrm{p}=0.047)$. Mean HR, and mean right and left eye 
bioRxiv preprint doi: https://doi.org/10.1101/634717; this version posted May 13, 2019. The copyright holder for this preprint (which was

21 temperature did not differ significantly between treatments in any phase (all $\mathrm{p}>0.05$ ). The findings of this study

22 suggest the application of a tongue-tie causes changes to both behavioural and physiological parameters suggestive

23 of a stress-related response. Further research is needed that will enable racing and sport horse regulatory bodies

24 to make informed decisions about the appropriate use of tongue-ties in horses.

26 Keywords: tongue-tie; horse; welfare; cortisol; thermography

\section{Introduction}

28 The tongue-tie (TT is a form of tack modification that has been used in horses for over 100 years (Fleming, 1889).

29 The device is used to hold the tongue in a fixed position and may be made from a rubber band, leather strap, nylon

30 stocking or similar material, that is tied below the jaw or at either side of the horse's mouth to the bit, after being

31 looped around the tongue. Early reports suggest that TTs were used to prevent abnormal noise and airway

32 obstruction arising as a result of the horse "retracting the tongue so as to force back the soft palate to such an extent

33 that it interferes with the passage of air between the nasal passages and the larynx" (Fleming, 1898). Today, TT

34 use remains commonplace in both Standardbred and Thoroughbred racehorses, throughout the world (1-6). Their

35 primary putative purposes are firstly to conservatively address airway patency issues, principally due to dorsal

36 displacement of the soft palate (DDSP) and improve performance and secondly, to aid control of the horse by

37 preventing it from getting its tongue over the bit $(3,6,7)$. Dorsal displacement of the soft palate, one of the most

38 common causes of dynamic airway obstruction during strenuous exercise is thought to affect approximately $20 \%$

39 of racehorses (Pollock et al. 2009; Priest et al., 2012.). Tongue-ties are frequently used as the first line of

40 conservative treatment by trainers and may also be used in combination with surgical management (Franklin et

41 al., 2001; Barakzai and Dixon, 2005; Barakzai et al., 2009a). However, the efficacy and the exact mechanism by

42 which the TT may aid in prevention of DDSP remains controversial (Beard et al. 2001; Cornelisse et al. 2001;

43 Franklin et al. 2002; $(5,8)$.

44 Over recent years, concerns regarding potential welfare issues associated with TT use have been raised by animal welfare organisations (Barakzai, 2009b). This has led to these devices being banned from a number of equestrian disciplines under Federation Equestre Internationale regulations (9). Anecdotal reports suggest that routine TT application may cause damage to the tongue (including lacerations, dysphagia, bruising, swelling, discolouration and paralysis) (10). A recent South Australian survey identified that $26.3 \%$ of Standardbred racehorse trainers reported complications relating to tongue-tie use, mostly associated with swelling of and superficial cuts to the 
bioRxiv preprint doi: https://doi.org/10.1101/634717; this version posted May 13, 2019. The copyright holder for this preprint (which was

not certified by peer review) is the author/funder, who has granted bioRxiv a license to display the preprint in perpetuity. It is made available under aCC-BY 4.0 International license.

51 ties were not well tolerated in young Thoroughbred racehorses (12). This implies that the horses must habituate to

52 the aversiveness of the procedure (McGreevy and McLean, 2010). It is not clear how long horses take to habituate

53 to TTs and whether they ever do so completely. Whenever sustained pressure is used to modify horse behaviour,

54 the principles of ethical training as espoused by the International Society for Equitation Science (ISES 2011) are

55 compromised and negative reinforcement that relies on the release of pressure, cannot take place. The application

56 of various training devices in horses, including bit attachments and restrictive nosebands, have been reported to

57 result in pain and stress responses, thus compromising welfare (13-15).

58 Appropriate assessment of stress in animals involves the integration of measurement of both behaviour and 59 physiology. Changes in behaviour can provide a useful and immediate means of assessing the response of an 60 animal to its environment, and shifts in demeanour, posture, gait and interactive behaviour may be associated with 61 presence of pain or stress (16). Head behaviours (such as head-shaking/-tossing and ear positioning) as well as 62 oral behaviours (gaping and lip-licking), have been used to estimate an animal's affective state (17). To date, the 63 physiological assessment of stress in horses has been based primarily on changes in endocrine function (18), as 64 well as parameters that reflect changes in autonomic functioning including heart rate and eye temperature (ET) 65 (18-20). Salivary cortisol concentration is established as a non-invasive indicator of stress because it reflects 66 activation of the hypothalamo-pituitary-adrenocortical axis (HPA) $(21,22)$. Measurement of maximum ET using 67 infrared thermography has the potential to assess both acute and chronic stress in animals, reflecting changes to 68 peripheral blood flow during increased sympathetic output (22-25). Heart rate variability (HRV) is a measure of 69 autonomic function and can be used to determine the balance between sympathetic and parasympathetic tone (20, $70 \quad 24,26,27)$.

71 The effect of tongue-tie application on stress responses in horses has not yet been investigated. The aim of this 72 study was to determine the effect of TT application on stress responses in resting horses. It was hypothesised that 73 the application of a TT would induce a stress response, resulting in increased concentration of salivary cortisol,

74 ET, HR and conflict/agitated behaviours. We also hypothesised that the stress response would be exacerbated in 75 horses that were naive to TT application. 


\section{Animals and husbandry}

80 This study used Standardbred horses $(n=12)$, comprising mares $(n=8)$ and geldings $(n=4)$ aged $11.5 \pm 3.0$ years 81 (mean \pm s.d) and weighing $487 \pm 33.9 \mathrm{~kg}$ (mean \pm s.d). Animals were subjected to a health check prior to the trial, 82 and deemed free from illness or injury. On experimental days, horses were brought in from the paddock, and 83 housed in day yards before being secured in stocks during the experiment. Horses wore a halter only, with no bit 84 and were loosely tied with a rope to the side bar of the stocks. All procedures were approved by the University of 85 Adelaide Animal Ethics Committee (S-2015-141, 02/07/2015), and performed in accordance with the Australian

86 Code of Practice for the Care and Use of Animals for Scientific Purposes, $8^{\text {th }}$ addition (2013) (28).

\section{Experimental Design}

88 The study was based on a randomised crossover design comprising two treatment groups: tongue-tie application 89 (TTA), and control (C). Horses were classified as either naive $(n=6)$ or having previous experience of TTA during

90 their racing careers $(n=6)$. Horses were pseudo-randomised and assigned to treatments so that 6 horses $(3$ 91 experienced and 3 naïve to TT), would have TTA on day 1 followed by C on Day 2, and 6 horses ( 3 experienced 92 and 3 naive), received C on Day 1 followed by TTA on Day 2. For each horse, treatments were performed at the 93 same time on both days to take account of diurnal rhythm in physiological parameters. For each treatment, horses 94 were observed for a total of 80 minutes, which was divided into three phases (Phase 1: 30-minute baseline; Phase 95 2: 20-minute treatment; and Phase 3: 30-minute recovery). The application of a TT was performed by the same 96 operator, using a rubber band measuring $152 \mathrm{~mm} \times 15 \mathrm{~mm}$ (Belgrave rubber band; size 106; 97 www.quillstationary.com.au). Following industry practice, the band was looped twice around the tongue, and then 98 secured to the lower jaw by looping the TT around the mandible (Figure 1). A new tongue-tie was used for each 99 horse. The duration of 20 minutes was based on the median duration of TT use reported during training and racing 100 in a previous study (Findley et al.,2015). During C, tongue manipulation was performed for 30 seconds at the start 101 of phase 2. This involved grasping of the tongue to mimic the initial process required for application of a TT,

102 however no TT was placed. On each experimental day, horses were brought into the barn in pairs, and individually 103 restrained within stocks for 10 minutes to acclimatise to the surroundings and to allow instrumentation of the 104 horses. During each treatment period, as one horse was treated, the other stood by, as a companion. 
bioRxiv preprint doi: https://doi org/101101/634717; this version posted May 13, 2019. The copyright holder for this preprint (which was not certified by peer review) is the author/funder, who has granted bioRxiv a license to display the preprint in perpetuity. It is made available under aCC-BY 4.0 International license.

\section{Fitting a tongue-tie to a racehorse}

1 Tongue-ties can be fashioned from nylon stockings, loops of leather or elastic.

Racing Australia's Register of Approved Gear states that they must be at least $15 \mathrm{~mm}$ wide.

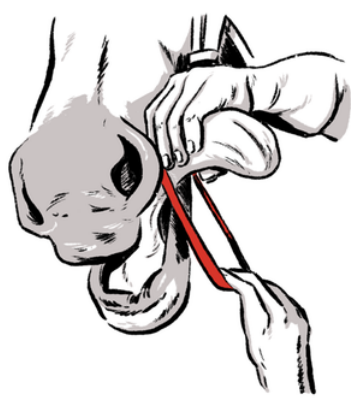

(3) To avoid the tongue becoming free, it is important to ensnare it with the tongue-tie by applying one or more loops around the tongue.

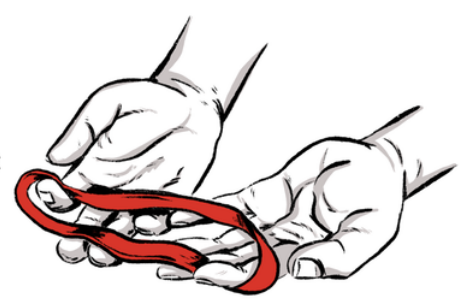

2 Horse tongues are muscular and slippery, so the first task is to grip the tongue manually.
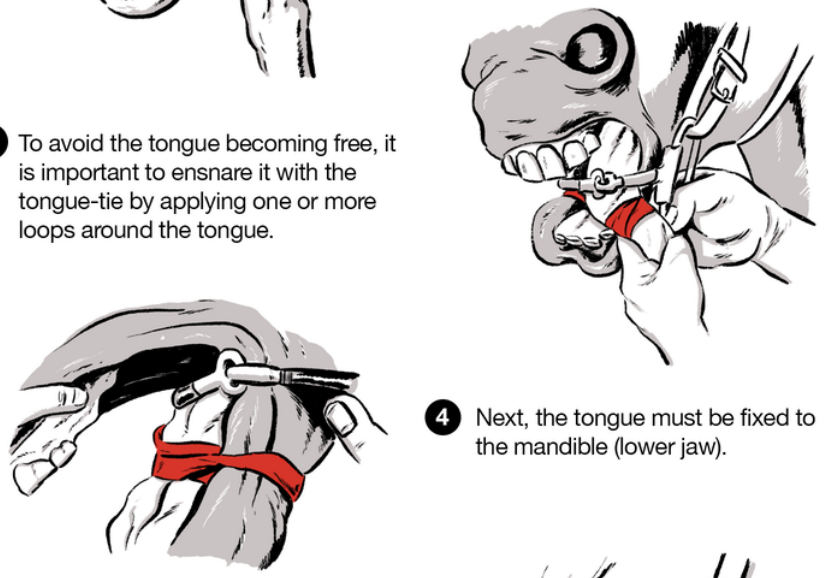

(4) Next, the tongue must be fixed to the mandible (lower jaw).

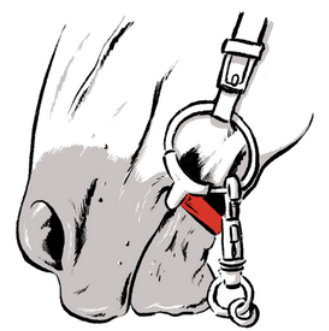

106 Figure 1 Horse with elastic tongue-tie in place. In alignment with industry practice, the device is looped twice around the tongue, and then the tongue secured to the lower mandible. NB: The horses in the current study did not wear bits. (Illustration from (29), republished under Creative Commons licence.)

\section{Behavioural Measures}

111 Behavioural data were recorded using two digital cameras (GoPro® HERO3), each mounted on a tripod placed at

112 either side of the stock at $90^{\circ}$ to the horse's head, at a distance of $1.5 \mathrm{~m}$. Recording commenced at the start of Phase

1131 and ceased after completion of Phase 3. The behaviours recorded from the video record included oral (gaping,

114 lip-licking) and head-related behaviours (head-tossing, ear positioning), that have previously categorised as either 115 positive/relaxed or negative/agitated (Table 1) (17). Behaviours were measured as a duration (\% of time), apart

116 from lip-licking which was measured as a frequency (n). Video clips of ten minute duration (last ten minutes of 117 phase 1 all of phase 2 and the first and last 10 minutes of phase 3) were used for behavioural analysis using 
bioRxiv preprint doi: https://doi org/101101/634717; this version posted May 13, 2019. The copyright holder for this preprint (which was not certified by peer review) is the author/funder, who has granted bioRxiv a license to display the preprint in perpetuity. It is made available under aCC-BY 4.0 International license.

118 behaviour analysis software (Mangold International GMbH, version interact 8) (Table 2). Analysis could not be

119 blinded because it was not possible to obscure the observer's view of the tongue. All behavioural analysis was

120 conducted by the same observer to minimise inter-observer variation.

121

122 Table 1: Head-related and oral behaviours recorded in horses during and after tongue-tie application or tongue 123 manipulation. Behaviours were categorised as either positive/relaxed or negative/agitated (17).

\begin{tabular}{|c|l|l|l|}
\hline Behaviour & Category & Description & Measurement \\
\hline Head-tossing & Agitated/ & Repeated throwing/tossing of the head either in an & Duration (\%) \\
& conflict & dorsal, ventral or lateral direction & Duration (\%) \\
\hline Ears back & Agitated & Ears were in a backwards position; both pinnae facing & Duration (\%) \\
\hline Ears forward & Relaxed & Ears were in a forward position; both pinnae facing & \\
\hline Lip-licking & Ambiguous & Protrusion of the tongue to lick the lower or upper lips. & Frequency (n) \\
\hline Gaping & Conflict & Repeated opening of the mouth such that space is & Duration (\%) \\
& & visible between upper and lower jaw & \\
\hline
\end{tabular}

126 Table 2: Descriptions of the phases and time points for analysis of behaviours.

\begin{tabular}{|c|c|c|}
\hline Phase & Time point (minutes) & Description \\
\hline 1 & $20-30$ & Baseline \\
\hline 2 & $0-10$ & T1 \\
\hline 2 & $10-20$ & T2 \\
\hline 3 & $0-10$ & Post1 \\
\hline 3 & $20-30$ & Post2 \\
\hline
\end{tabular}


bioRxiv preprint doi: https://doi.org/10.1101/634717; this version posted May 13, 2019. The copyright holder for this preprint (which was not certified by peer review) is the author/funder, who has granted bioRxiv a license to display the preprint in perpetuity. It is made available under aCC-BY 4.0 International license.

\section{Physiological measures}

\section{Salivary Cortisol}

131 Saliva samples were collected using Salivette ${ }^{\circledR}$ (Sarstedt, Sweden) swabs, at the end of each phase. The swab was

132 placed in the horse's oral cavity (between the cheek and the teeth) using surgical forceps and moved around gently

133 for 30 seconds. Swabs were stored on ice before being transported to the laboratory, where the tubes were

134 centrifuged $\left(1000 \mathrm{~g}\right.$ for 10 minutes) and samples frozen at $-20^{\circ} \mathrm{C}$ until later analysis. The saliva was analysed for

135 cortisol concentration, using a commercially available ABOR Enzyme-linked immunosorbent assay (ELISA)

136 (Ann Arbor, Michigan 48108-3284 United States). Sensitivity and limit of detection were determined to be 17.3

$137 \mathrm{pg} / \mathrm{mL}$ and $45.4 \mathrm{pg} / \mathrm{mL}$, respectively. All samples were run in duplicate and results expressed as pg/mL. The intra138 assay coefficient of variation determined from duplicates of a control saliva sample in each assay plate $(\mathrm{n}=3)$ was

$139 \quad 16.7 \%$ and the inter-assay coefficient of variation was $5.9 \%$.

\section{Eye temperature}

141 An infrared camera (ThermaCam S60, FLIR Systems AB, Danderyd, Sweden) was used to collect thermographic 142 images of the eye at 5-minute intervals for the duration of the study period, as per previous studies (Yarnell et al., 143 2013). At each time point, three images were taken of the right and left eye, and the clearest of the three used for 144 analysis. Images were taken $90^{\circ}$ from the front of the horse at a distance of $0.5-1.0$ meters. Atmospheric 145 temperature and relative humidity were recorded every 30 minutes from the Bureau of Meteorology (BOM) 146 Roseworthy weather station, and values calibrated during image analysis. Maximum eye temperature $\left({ }^{\circ} \mathrm{C}\right)$ was 147 determined using FLIR Tools version 5.6, (FLIR Systems AB, Danderyd, Sweden), with the analysis of 148 temperature taken from within the medial posterior palpebral border of the lower eyelid and lacrimal caruncle 149 (Figure 2). 
bioRxiv preprint doi: https://doi.org/10.1101/634717; this version posted May 13, 2019. The copyright holder for this preprint (which was not certified by peer review) is the author/funder, who has granted bioRxiv a license to display the preprint in perpetuity. It is made available under aCC-BY 4.0 International license.

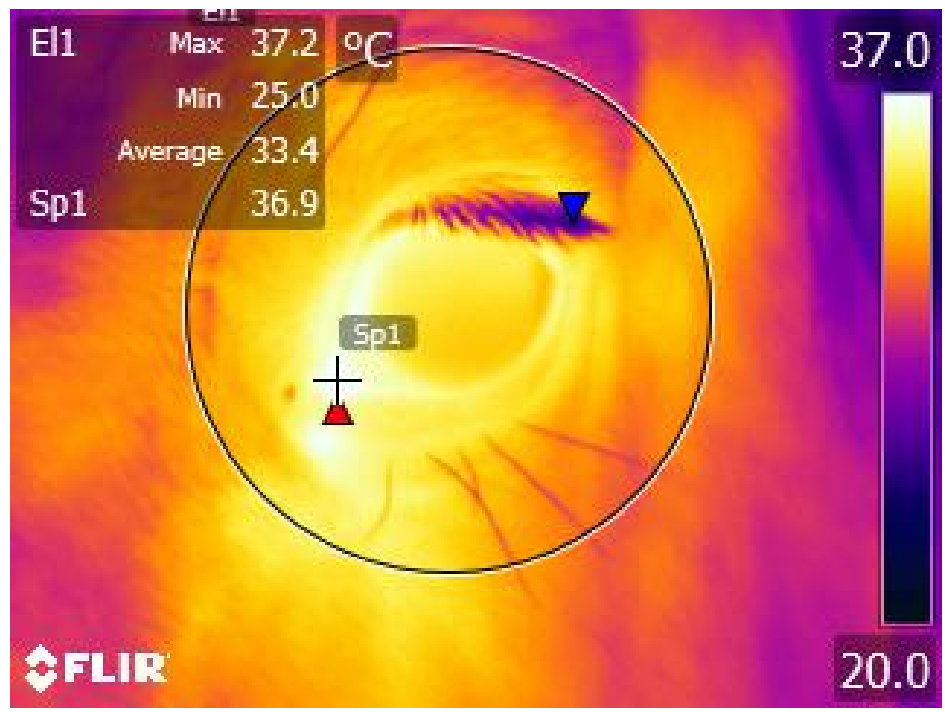

152 Figure 2: Thermographic image taken of a horse's left eye. Maximum eye temperature was taken from within the medial posterior palpebral border of the lower eyelid and lacrimal caruncle.

\section{Heart Rate}

156 Heart rate was recorded using a telemetric ECG system (Televet 100; Engel Engineering Service GmbH; 63150

157 Heusenstamm, Germany). Adhesive electrodes were attached to the skin of the thorax in a modified base-apex 158 configuration (with the left arm $(+)$ and left leg $(+)$ electrodes placed on the thorax, over the apex of the heart and 159 the right arm (-) and reference electrodes placed over the left shoulder). These were connected to the Televet unit, 160 which was fixed to a surcingle. ECG data was recorded onto a SD card and uploaded to a laptop computer after 161 the conclusion of the test. The Televet software was used to calculate RR intervals (using a cut off value of $20 \%$ 162 maximum deviation of consecutive RR intervals). ECG traces were checked and artefacts corrected manually prior 163 to subsequent analysis.

\section{Statistical Analysis}

165 Statistical analysis was performed using SPSS 23 (SPSS Inc., Chicago, IL, USA) Data are reported as mean \pm 166 SEM. Data were tested for normality and homogeneity using the Kolomogorov-Smirnov and Levene test, respectively. Non-normally distributed data were $\log 10$ transformed. A linear mixed-effects model was used to 168 analyse mean behaviour, salivary cortisol concentration, eye temperature and heart rate. Behaviour data were analysed from the last 10 minutes during phase 1 , all of phase 2 and the first and last 10 minutes of phase 3 . The model included fixed effects (treatment type, day, time, previous experience, sex and treatment sequence), and random effects (Horse ID). Baseline measurements for mean salivary cortisol concentration, eye temperature and

172 heart rate were included as a covariate due to high inter-horse variability at baseline. A repeated measures general linear model was used to determine differences within treatments over time for both behaviour and physiological 
bioRxiv preprint doi: https://doi.org/10.1101/634717; this version posted May 13, 2019. The copyright holder for this preprint (which was not certified by peer review) is the author/funder, who has granted bioRxiv a license to display the preprint in perpetuity. It is made available under aCC-BY 4.0 International license.

174 parameters, using within-subject effects of time, and between-subject effects as treatment. Variables were

175 considered significantly different when $\mathrm{p}<0.05$.

176

Results

177

178

\section{Behavioural assessment}

179

$180 \quad$ Head-tossing

181 Horses spent significantly more time head-tossing during TTA than C in both T1 $(21.3 \% \pm 3.6 \%$ vs $1.1 \% \pm 0.4$ $\% ; \mathrm{p}=0.001)$, and T2 $(26.0 \% \pm 3.7 \%$ vs $0.6 \% \pm 0.2 \% ; \mathrm{p}=0.001)$ (Figure 3$)$. A significant association was observed between previous TT experience and head-tossing behaviour, in that horses with previous exposure to TT tossed their heads for longer $(26.7 \% \pm 5.6 \%)$ at $\mathrm{T} 1$ than naive horses $(16.0 \% \pm 3.6 \%)(\mathrm{p}=0.04$; Figure 4$)$. No other factors had a significant effect on head-tossing.

80

70

60

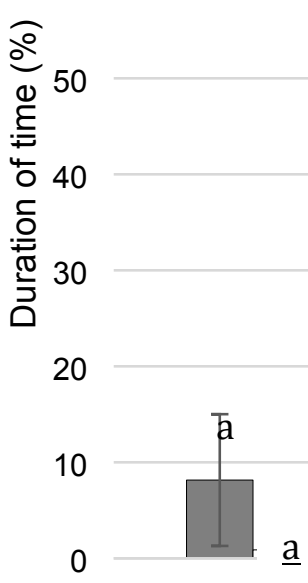

Baseline
$\mathrm{T} 1$

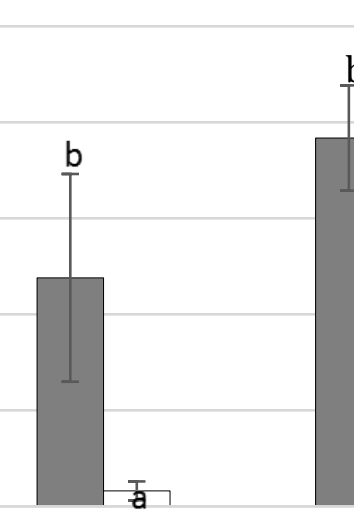

Period of measurment

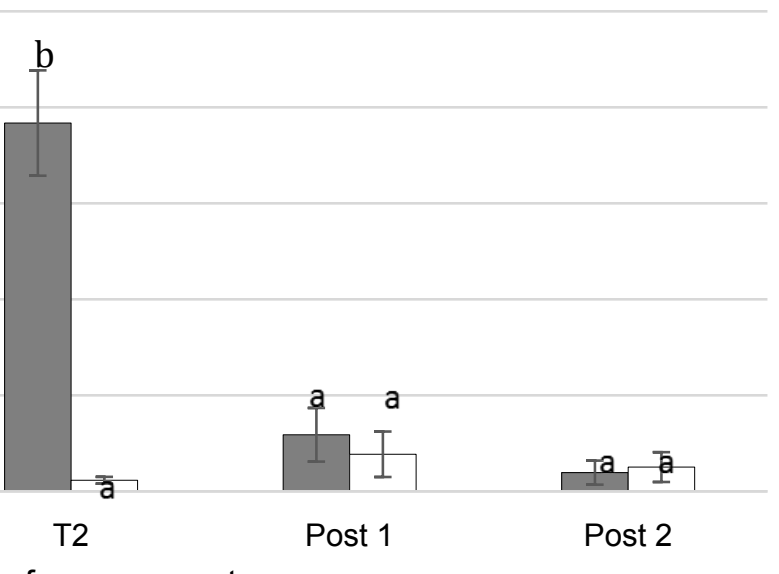

186

Figure 3: Mean $( \pm \mathrm{SEM})$ percentage of time spent displaying head-tossing behaviour $(\%)$ for TTA and C groups over time. Values indicated with different subscripts $(a, b)$ are significantly different $(p<0.05)$. Key: Baseline $=10$ minutes before treatment; $\mathrm{T} 1=$ first 10 minutes of treatment phase; $\mathrm{T} 2=$ last 10 minutes of treatment phase; post $1=$ first 10 minutes of recovery; post $2=$ last 10 minutes of recovery) 
bioRxiv preprint doi: https://doi.org/10.1101/634717; this version posted May 13, 2019. The copyright holder for this preprint (which was not certified by peer review) is the author/funder, who has granted bioRxiv a license to display the preprint in perpetuity. It is made available under aCC-BY 4.0 International license.

191

192

193

194

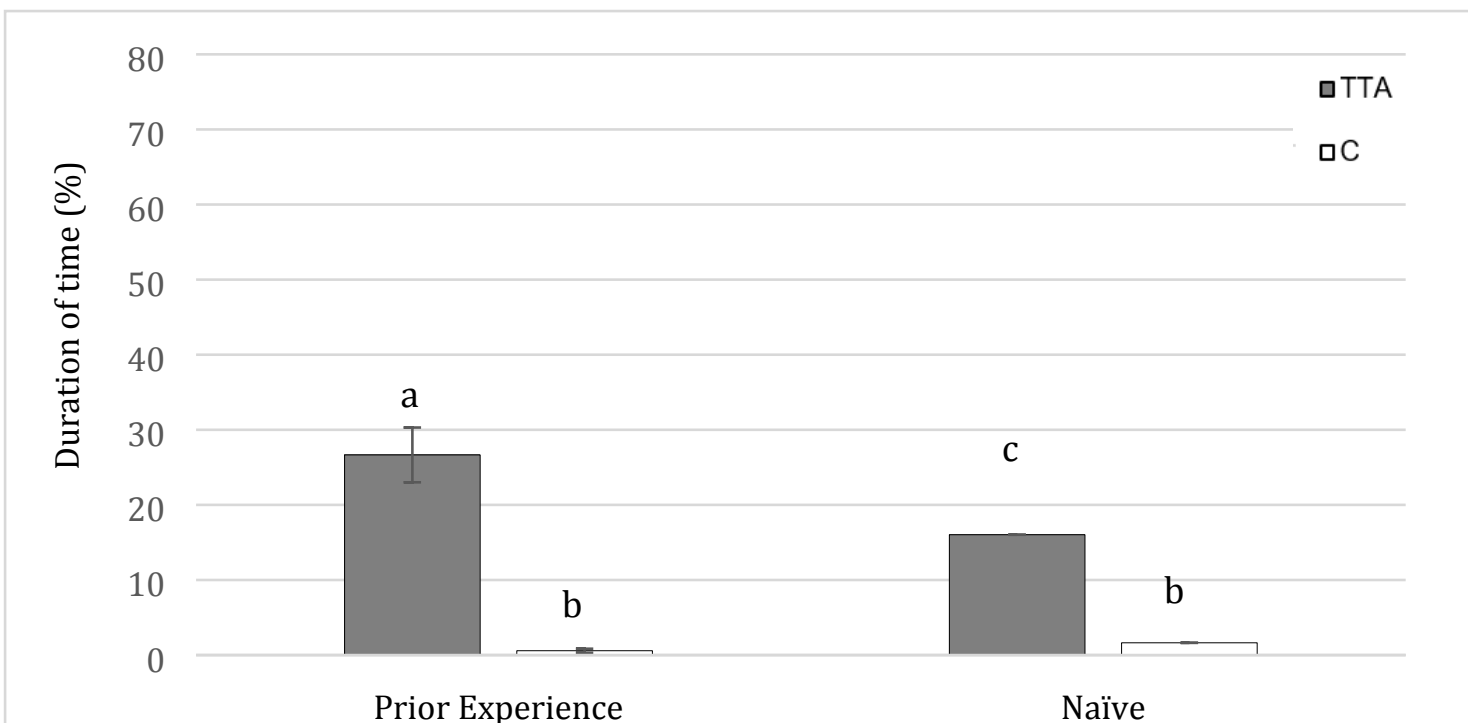

195 Figure 4: Mean \pm SEM time spent displaying head-tossing behaviour (\%) of naïve vs horses with prior experience

196 of TT during TTA and C. Values with different subscripts $(a, b, c)$ are significantly different $(\mathrm{p}<0.05)$.

197 
bioRxiv preprint doi: https://doi.org/101101/634717; this version posted May 13, 2019. The copyright holder for this preprint (which was not certified by peer review) is the author/funder, who has granted bioRxiv a license to display the preprint in perpetuity. It is made available under aCC-BY 4.0 International license.

\section{Ear position}

199 Horses undergoing TTA spent significantly more time with their ears in a backwards position than C at three time 200 points: T1 $(62.6 \% \pm 4.8 \%$ vs $9.4 \% \pm 2.1 \% ; \mathrm{p}<0.001), \mathrm{T} 2(74.7 \% \pm 4.6 \%$ vs $9.3 \% \pm 2.7 \%$; $<<0.001)$ and Post

$2011(18.9 \% \pm 6.6 \%$ vs $9.0 \% \pm 2.1 \% ; p=0.021)$ (Figure 5). Correspondingly, there was a significant difference in 202 the time spent with their ears forwards in C compared to TTA at T1 $(27.5 \% \pm 3.3 \%$ vs $3.1 \% \pm 0.8 \%$; $<<0.001)$ 203 and T2 $(29.3 \% \pm 5.2$ vs $3.4 \% \pm 0.7 \% ; \mathrm{p}<0.001)$.

204 Horses spent more time with their ears backwards with increasing time wearing the TT: there was a significant difference between $\mathrm{T} 1$ and $\mathrm{T} 2,(\mathrm{p}<0.001)$ (figure 5). Once the TT was removed the time spent with ears in a backwards position was significantly decreased compared with $\mathrm{T} 1$ and $\mathrm{T} 2(\mathrm{P}<0.001)$ (Figure 5).

207 Time of testing also had an effect at T2, with afternoon-tested horses spending more time with their ears backwards 208 than morning-tested horses $(47.8 \% \pm 7.1 \%$ vs $37.8 \% \pm 6.5 \% ; p=0.041)$. At Post 1 , horses spent significantly more time with ears backwards on Day 1 compared to Day $2(19.0 \% \pm 6.6 \%$ vs $9.2 \% \pm 2.2 \% ; p=0.025)$.

210 Accordingly, during Post 1, horses spent less time with ears facing forward on Day 1 compared to Day 2 (24.4 \%

$211 \pm 3.3 \%$ vs $32.1 \% \pm 2.4 \% ; \mathrm{p}=0.010)$.

212 An interaction between previous experience and treatment showed horses with prior experience of tongue-ties 213 spent less time with ears forward compared to naive horses at Post $1(21.3 \% \pm 6.5 \%$ vs $28.5 \% \pm 3.3 \%$; $p=0.032)$.

214 No other factors had a significant relationship with ear position

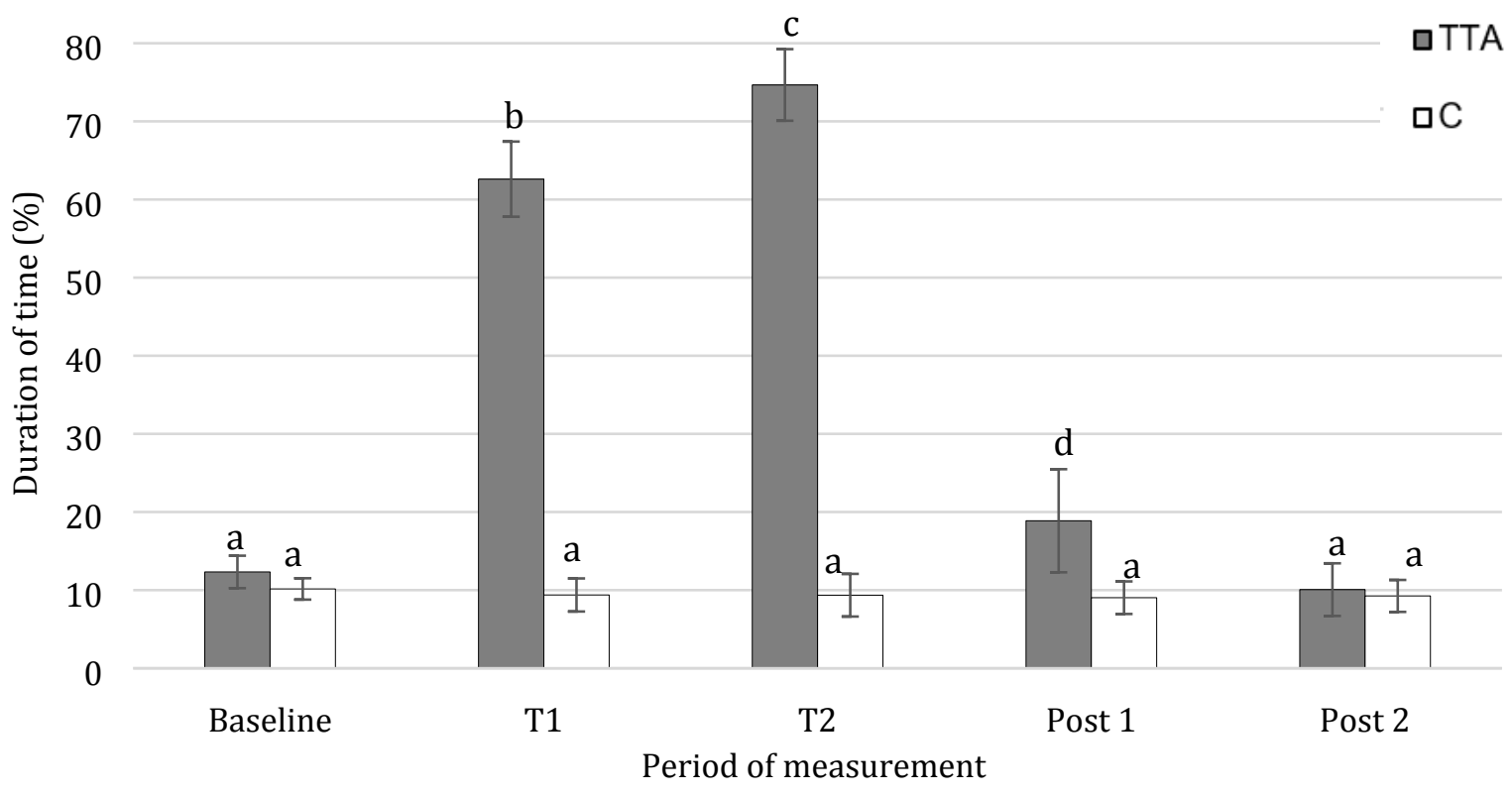


bioRxiv preprint doi: https://doi.org/10.1101/634717; this version posted May 13, 2019. The copyright holder for this preprint (which was not certified by peer review) is the author/funder, who has granted bioRxiv a license to display the preprint in perpetuity. It is made available under aCC-BY 4.0 International license.

218 Figure 5: Mean duration of ears positioned backwards of horses $(n=12)$ in TT and C throughout trial. ${ }^{a-b-c-d}$ Values

219 indicated with different subscripts are significantly different $(\mathrm{p}<0.05)$.

\section{Gaping}

222 No horses showed gaping behaviour during the baseline recordings. In C, no gaping was observed in any horse 223 throughout the recording period. However, during TTA, horses spent significant amounts of time showing gaping 224 behaviour both at T1 $(58.2 \% \pm 3.4 \%$ TTA vs $0.0 \% \pm 0.0 \% \mathrm{C} ; \mathrm{p}<0.001)$ and T2 $(48.9 \% \pm 3.7 \%$ TTA vs $0.0 \%$ $225 \pm 0.0 \% \mathrm{C} ; \mathrm{p}<0.001)$ (Figure 6). Gaping declined significantly after TT removal $(4.60 \%+/-0.66 \%) \mathrm{p}<0.001$ 226 during post 1) and no gaping was observed by 20 minutes post removal.

227 There was a significant interaction between previous TT experience and gaping behaviour: horses with previous experience of TT gaped more than naive horses at T2 $(58.1 \% \pm 2.6 \%$ vs $48.9 \% \pm 4.3 \%$; $=0.030)$. No other factors had a significant relationship with gaping.

230

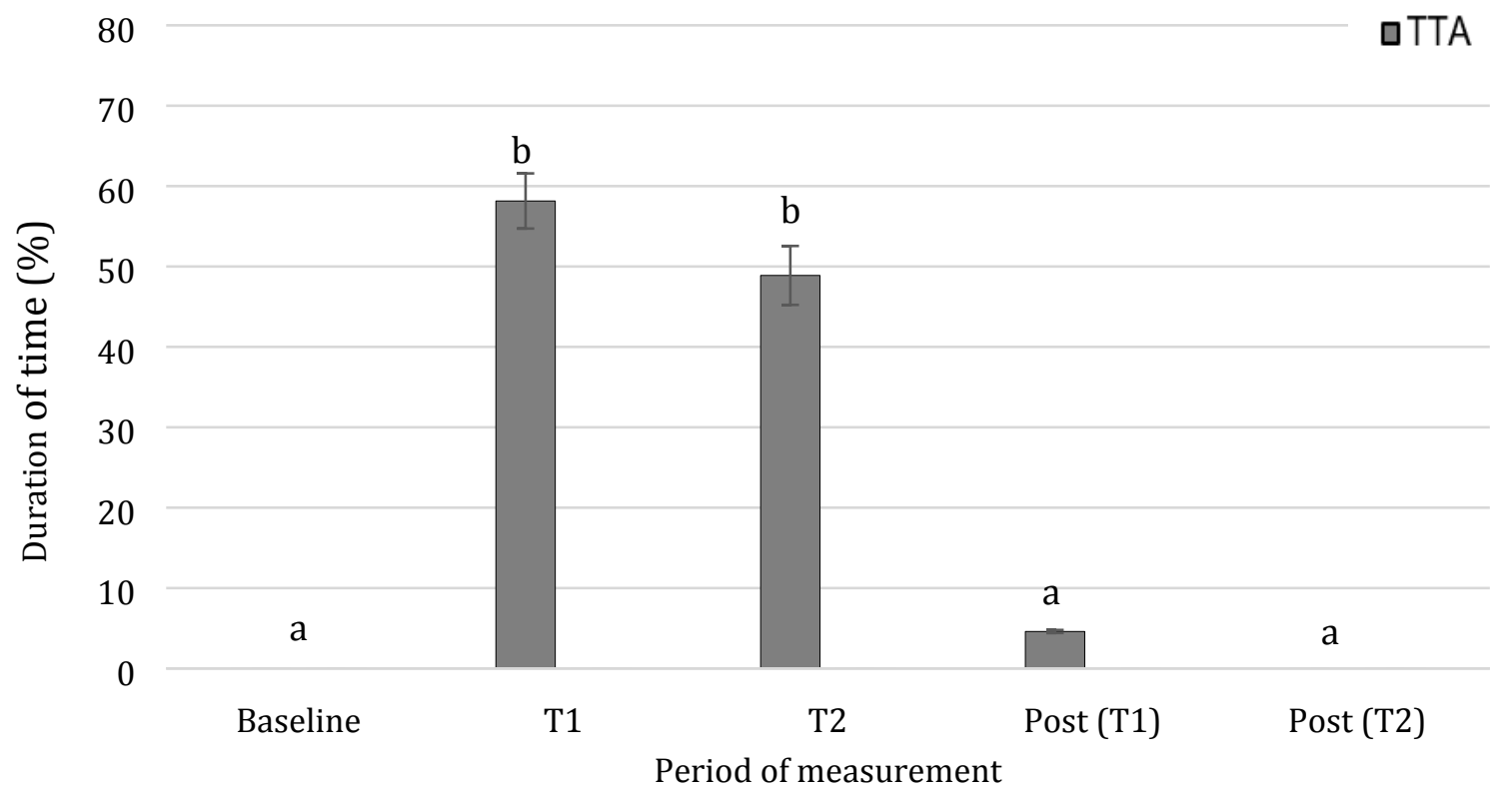

232 Figure 6: Mean duration of gaping behaviour of horses $(n=12)$ during TTA throughout trial. ${ }^{a-b}$ Values indicated 233 with different subscripts are significantly different $(\mathrm{p}<0.05)$. 
bioRxiv preprint doi: https://doi.org/10.1101/634717; this version posted May 13, 2019. The copyright holder for this preprint (which was not certified by peer review) is the author/funder, who has granted bioRxiv a license to display the preprint in perpetuity. It is made available under aCC-BY 4.0 International license.

\section{Lip-licking}

237 Lip-licking was observed significantly more frequently in TTA than in C at Baseline $(12.8 \pm 2.7$ vs $6.3 \pm 1.7$;

$238 \mathrm{p}=0.014)$, Post $1(32.9 \pm 4.1$ v $3.8 \pm 1.40 ; \mathrm{p}<0.001)$ and Post $2(20.1 \pm 2.2$ vs $3.6 \pm 1.0 ; \mathrm{p}<0.001)$ (Figure 7$)$. Lip

239 licking was not possible during TTA due to the tongue being secured to the mandible. However, there was a 240 significant increase in lip licking following TT removal at Post $1(32.02 \pm 14.29 ; \mathrm{p}<0.001)$, and Post $2(20.08 \pm$

2417.63 TTA; $<<0.001)$ compared to baseline $(12.08 \pm 2.31 ; \mathrm{p}<0.001)$, Subsequently, there was a significant reduction 242 in lip-licking between Post 1 and Post $2(32.9 \pm 4.1$ vs $20.1 \pm 2.2 ; \mathrm{p}<0.001)$.

243

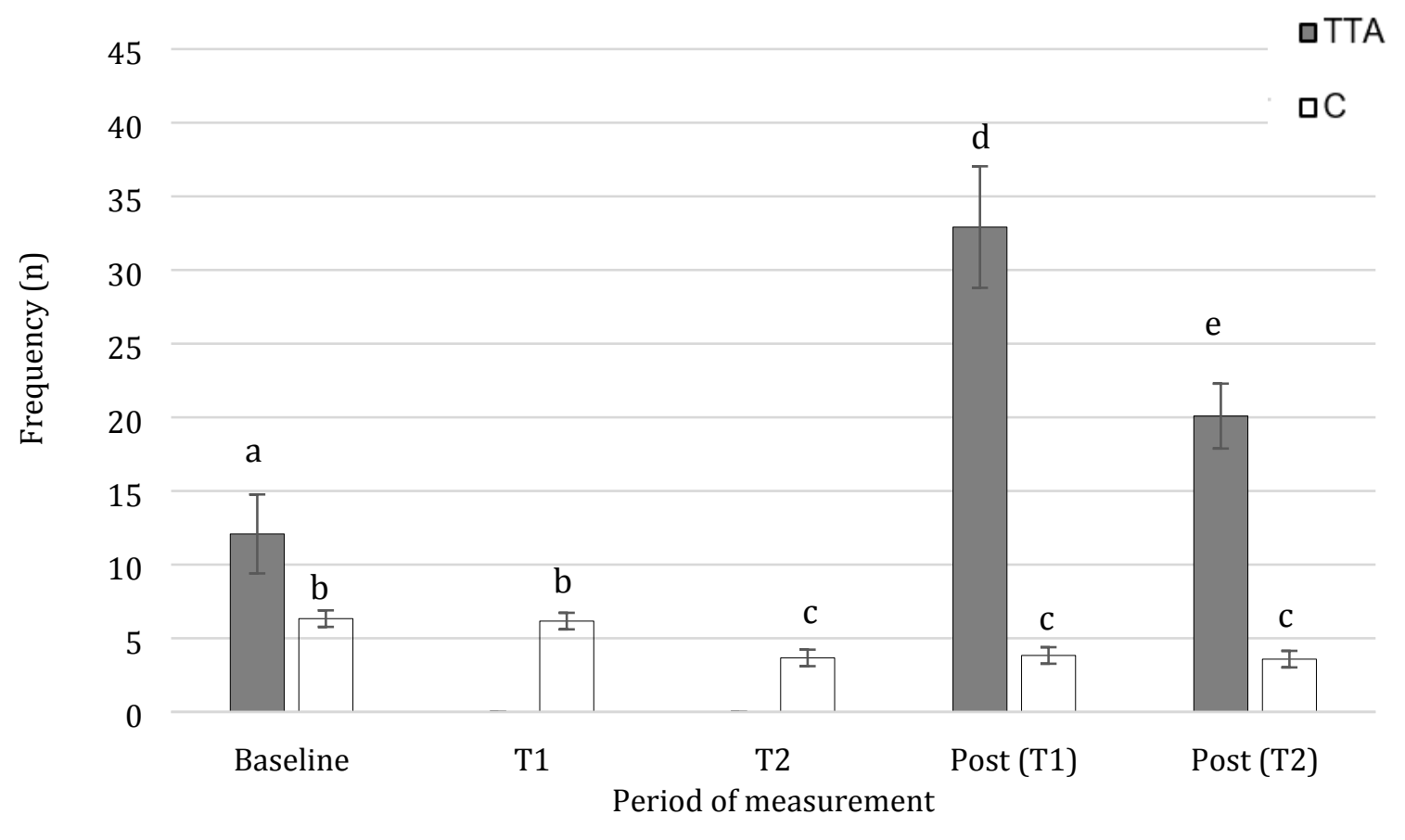

245 Figure 7: Mean frequency of lip-licking behaviour of horses $(n=12)$ during TTA and C throughout trial. ${ }^{\text {a-b-c-d-e }}$

246 Values indicated with different subscripts are significantly different $(\mathrm{p}<0.05)$.

\section{Physiological assessment}

\section{Cortisol}

249 Salivary cortisol concentration did not differ between horses with TTA and C at Phase $1(p=1.29)$ or phase $2(p=$

250 0.89). A significant difference in saliva cortisol concentration was observed between horses at Phase 3, with horses

251 showing increased salivary cortisol concentrations after TTA than compared to C (1846.1pg/mL $\pm 478.3 \mathrm{pg} / \mathrm{mL} \mathrm{vs}$

252 1253.6pg/mL $\pm 491.6 \mathrm{pg} / \mathrm{mL} ; \mathrm{p}=0.047)$ (Figure 8). 
bioRxiv preprint doi: https://doi.org/101101/634717; this version posted May 13, 2019. The copyright holder for this preprint (which was not certified by peer review) is the author/funder, who has granted bioRxiv a license to display the preprint in perpetuity. It is made available under aCC-BY 4.0 International license.

253

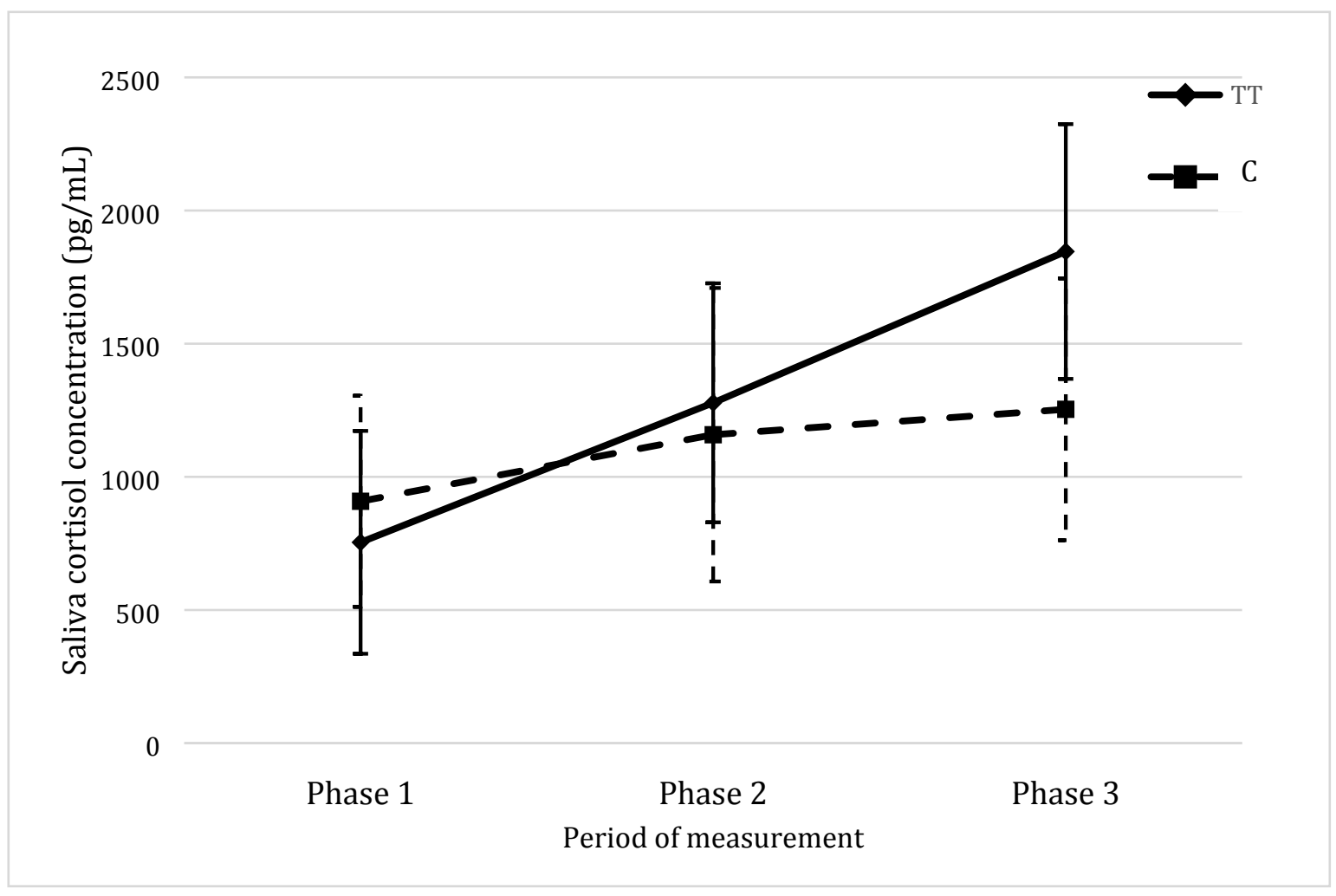

254 Figure 8: Mean saliva cortisol concentration $(\mathrm{pg} / \mathrm{mL})$ in TTA and $\mathrm{C}$ throughout trial.

\section{Eye temperature}

257 No significant difference in mean right and left eye temperature was observed between treatments during any

258 phase of the experiment Phase $1\left(36.1 \pm 0.08^{\circ} \mathrm{C}\right.$ TTA vs $36.2 \pm 0.10^{\circ} \mathrm{C} ; \mathrm{p}=0.485$ and $36.25 \pm 0.10^{\circ} \mathrm{C}$ TTA vs 36.4

$\left.259 \pm 0.13^{\circ} \mathrm{C} ; \mathrm{p}=0.463\right)$, Phase $2\left(36.2 \pm 0.16^{\circ} \mathrm{C}\right.$ TTA vs $36.3 \pm 0.10^{\circ} \mathrm{C} ; \mathrm{p}=0.190$ and $36.3 \pm 0.11^{\circ} \mathrm{C}$ TTA vs $36.5 \pm$

$\left.2600.13^{\circ} \mathrm{C} ; \mathrm{p}=0.234\right)$ and Phase $3\left(36.1 \pm 0.08^{\circ} \mathrm{C}\right.$ TTA vs $36.4 \pm 0.18^{\circ} \mathrm{C} ; \mathrm{p}=0.215$ and $36.3 \pm 0.09^{\circ} \mathrm{C}$ TTA vs $36.5 \pm$ $\left.0.07^{\circ} \mathrm{C} ; \mathrm{p}=0.369\right)$, respectively.

\section{Heart rate}

263 Mean HR did not differ significantly between TTA and C at any time point (Figure 9). However, there was a

264 trend for horses in the TTA group to have a higher mean heart rate compared with $\mathrm{C}$ at T2 (43bpm $\pm 2.4 \mathrm{bpm}$ vs

$26537 \mathrm{bpm} \pm 2.5 \mathrm{bpm} ; \mathrm{p}=0.079$ ), followed by a reduction in HR in this group of horses after TT removal (figure 9) 


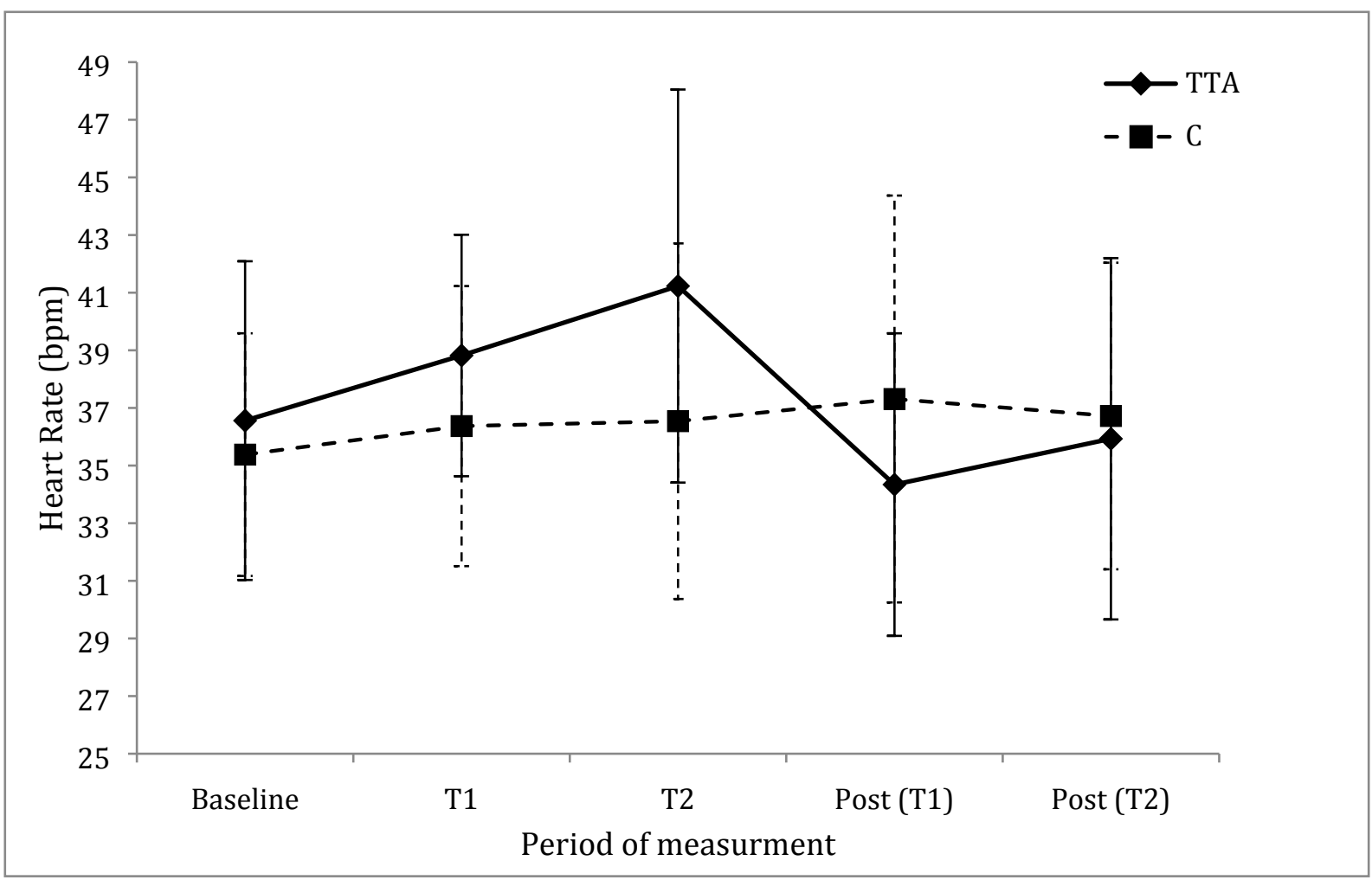

Figure 9: Mean heart rate (bpm) in TT and C throughout trial.

\section{Discussion}

272 In this study, both behavioural and physiological indices were used to investigate possible indicators of stress in

273 horses during and following TT application. The results support the hypothesis, suggesting TTA resulted in

274 changes to behavioural and physiological parameters that may be indicative of a stress response.

\section{Behavioural responses}

276 Behavioural responses to a discrete challenge can offer an immediate, easily identifiable and non-invasive means

277 of assessing an animal's affective state (17). Changes in the behaviours involving the head, ears and mouth have been reported to reflect horses in relaxed or agitated states (30). Conflict behaviour has been described as a response exhibited by animals that have difficulty coping with competing motivations associated with resistance to handling, training or equipment $(31,32)$. It is possible that horses wearing a TT are highly motivated to move their tongues and so they can be expected to attempt various oral and lingual manoeuvres to free themselves of the restraint.

\section{Head-tossing}

Head-tossing behaviour in horses has been shown to reflect agitated or conflict behaviour caused by irritation or pain to the mouth (33). In the current study, horses exposed to TTA spent significantly more time head-tossing 
bioRxiv preprint doi: https://doi.org/10.1101/634717; this version posted May 13,2019. The copyright holder for this preprint (which was

not certified by peer review) is the author/funder, who has granted bioRxiv a license to display the preprint in perpetuity. It is made available under aCC-BY 4.0 International license.

286 during Phase 2 compared to C, suggesting that the presence of a TT may be irritating and/or results in discomfort

287 or pain, inducing a negative affective state in these animals. Horses with previous experience to TTA showed more

288 head-tossing than those with no previous experience. A recent study found the application of TT was not well

289 tolerated by naïve horses, confirming the need for habituation (12). Habituation of novel stimuli by means of

290 repeated exposure to that stimulus, may allow animals to become accustomed to the environment and thus reduce

291 fear responsiveness (34). However, in the current study, habituation did not take place during the treatments nor

292 was there evidence of it having occurred before the treatments took place. Indeed, the frequency of head tossing

293 behavior increased between T1 and T2 and prior experience of TT use resulted in more behavioral responses to

294 them. Information on the horses' most recent previous exposure to TT, including the duration or tightness of

295 repeated exposure was not available for horses in this study. Therefore, future research should explore how horses'

296 attempts to remove TT decline over time. This is important because the eventual disappearance of attempts to

297 remove TT may be seen as either habituation or mark the point at which horses reach learned helplessness (Hall

298 et al 2007).

\section{$299 \quad$ Ear position}

300 Backwards positioning of the ears is reported to reflect negative affective states, including fear, discomfort, submission, avoidance, pain or aggression in horses (35-37). In our study, horses spent more time with their ears

302 backwards during TTA and immediately after removal compared to C. These findings align with those from a study of horses ridden with their necks in a hyper-flexed position, in that horses spent more time with ears

304 backwards when hyperflexed than when they were not hyperflexed, possibly suggesting an association between hyperflexion of the neck and a negative experience (38). During Phase 2, horses with TTA spent more time with their ears backwards at T2 than at T1. This may suggest that over the course of the 20 minutes of the current treatment, the horses' discomfort, submission, avoidance or discomfort increased. This is consistent with previous research showing that the intensity, duration and frequency of a stressor generally correlates with the intensity of the stress responses that manifest (39). During Post 1, the time spent with ears in a backwards position was also higher with TTA than C. This may suggest that horses subjected to TTA may still be recovering from the effects

311 of treatment into what we anticipated to be a wash-out period.

312 When horses have their ears facing in forwards are often regarded being relaxed or in a positive affective state

313 (40). Another study reported ears facing forward as a feature of horses displaying interest or pleasure towards 314 experienced handlers in contrast to inexperienced handlers (41). During TTA in the current study, horses spent 315 less time with their ears forward at T1 and T2. This may suggest that during TTA, horses are less relaxed than 316 during C. As with head-tossing, time spent with ears forwards was associated with previous experience. Horses 
bioRxiv preprint doi: https://doi.org/10.1101/634717; this version posted May 13, 2019. The copyright holder for this preprint (which was not certified by peer review) is the author/funder, who has granted bioRxiv a license to display the preprint in perpetuity. It is made available under aCC-BY 4.0 International license.

317 with prior experience of TTA showed decreased time with ears in a forward position compared to naïve horses.

318 Holding the ears back is recognised as a sign of pain (42) so this finding could is suggest that they have learned to 319 associate the sensation of having their tongues tied with a negative affective state. It may also suggest that the 320 experienced horses have learned that, rather than being swiftly transient, the restraint persists for some time.

\section{Gaping}

322 Gaping or opening of the mouth has been categorised as an agitated behaviour, where increases in this behaviour 323 may reflect a negative affective state in horses (17). Gaping has been suggested be a reflection of horses showing escape or avoidance type behaviours in response to the presence of a bit $(40,43)$. In the present study, no bit was

325 in place and horses did not perform gaping behaviour at any time point during C. Similarly, horses with TTA showed no gaping behaviour during Phase 1 or Post2. However, at Phase 2, there was increased gaping behaviour during TTA application. Some gaping behaviour was also observed in the 10 minutes after TT removal but this was significantly less than during TTA and was not significantly different to baseline or C. These findings suggest that when tongue-ties were in place, horses may have been performing gaping to avoid or escape the presence of tongue-tie. Similar, to other behavioural indices, gaping behaviour was influenced by previous experience to TTA, with, horses with previous experience to TT spending increased proportion of time performing gaping behaviour compared to naive horses.

\section{Lip-licking}

334 The frequency of lip-licking behaviour during TTA showed a significant decline from Baseline. This probably 335 reflects the fact that horses with tongue-ties are unable to physically perform lip-licking when their tongues are restrained. However, after TTA, horses showed significantly more lip-licking behaviour than at baseline which may represent post-inhibitory rebound behaviour. Post-inhibitory rebound behaviour is the term given to an increase in the expression of a behaviour following a period of restriction or deprivation $(44,45)$, that may indicate that the deprivation (of the opportunity to perform certain normal behaviours) has deleterious effects on welfare $(44,46)$. In a similar study that focussed on restrictive nosebands, a post-inhibitory rebound behaviour was observed for yawning, swallowing and lip-licking behaviour (23). That said, the authors of that study noted that post-inhibitory rebound behaviours were observed for all groups with varying noseband tightness, thus the horse's response may have been related to the novelty of having had two bits in the mouth rather that noseband tightness alone. Importantly, in the current study, no significant difference in lip-licking behaviour emerged between horses experienced to TTA and the naive horses, suggesting the post-inhibitory rebound response observed was likely due to the application of tongue-tie rather than any novelty effect. No significant difference in lip-licking was 
bioRxiv preprint doi: https://doi.org/10.1101/634717; this version posted May 13,2019. The copyright holder for this preprint (which was not certified by peer review) is the author/funder, who has granted bioRxiv a license to display the preprint in perpetuity. It is made available under aCC-BY 4.0 International license.

347 observed in horses during $\mathrm{C}$ treatment between Phases 1, 2 and 3, suggesting that the brief tongue manipulation

348 performed had no effect on the horses' motivation to lick their lips.

\section{Physiological responses}

350 When animals experience stressful stimuli, the body attempts to return to homeostasis by creating alterations in 351 neural, endocrine, immune, hematologic and metabolic functioning (47). Non-invasive sampling procedures 352 (including salivary cortisol, ET and HR), are considered more advantageous in some prey species, as the collection 353 method requires minimal disturbance to the animal and reduces the likelihood of anticipatory or nonspecific stress 354 responses $(48,49)$.

\section{Salivary cortisol}

356 Elevations of the concentration of glucocorticoid hormone cortisol are regularly used as an indicator of stress (50).

357 A positive correlation has been shown between salivary and plasma cortisol in horses (51). Salivary cortisol 358 provides a non-invasive alternative to plasma cortisol analysis, as blood collection via jugular venepuncture or 359 from jugular catheterisation can cause increase plasma cortisol concentration for up to 130 minutes (52). In the 360 present study, there was no difference in salivary cortisol concentration in horses during C, suggesting that the 361 saliva swabbing itself was not stressful for horses. Horses showed an increase in cortisol following TTA, suggesting that this training device posed enough discomfort to elicit a stress response. Although cortisol concentration did not differ between treatments at Phase 2, we would expect that the increase would be delayed as the time it takes free cortisol to increase in saliva post-stressor is approximately 30 minutes (53). Although baseline values were variable among individuals, the amount of change in cortisol after TTA is similar to previous studies that measured salivary cortisol in response to sham clipping in horses (25), as well as social isolation and the sound of fireworks (30). It is difficult to determine if salivary cortisol increased as a result from the inability to perform normal behaviours when TT is in place, from pain and stress, or a combination of both. However, the fact that TTA was enough to elicit a stress response, suggests that the training device may compromise welfare.

\section{Eye temperature}

371 Changes in eye temperature occur as a consequence of increased body temperature, as well as changes to peripheral 372 blood flow during increased sympathetic output (54). Images of the eye measured using an infrared thermographic 373 camera have been reported to provide a non-invasive method of assessing stress in animals. Previous research in 374 horses using infrared thermography has identified increased eye temperature in association with noseband 375 tightness $(23)$, exercise $(22,24)$ and fear tests $(55)$. However, others have reported that eye temperature is a poor 376 estimate of core body temperature and is not correlated with accepted measures of stress including heart rate and 377 salivary cortisol concentrations (Soroko et al., 2016). The results of this study found no significant difference in 
bioRxiv preprint doi: https://doi.org/10.1101/634717; this version posted May 13, 2019. The copyright holder for this preprint (which was

not certified by peer review) is the author/funder, who has granted bioRxiv a license to display the preprint in perpetuity. It is made available under aCC-BY 4.0 International license.

378 eye temperature between treatments, over time. Factors that may affect the degree of heat emitted from a surface

379 include sunlight, distance, temperature, humidity, and wind (54). All of these factors were included in the image 380 analysis however horses were loosely tied in stalls to allow for freedom for horses perform oral and head

381 behaviours. Given that all horses performed some degree of head-tossing during the trial, it is possible that when 382 taking images of the eye, the required distance of 0.5 -1meter was not always met and this may have influenced the 383 results.

\section{$384 \quad$ Heart rate}

385 Changes in heart rate have previously been used as a non-invasive measure stress in horses (20, 24, 26, 27). Heart 386 rate is regulated by both the sympathetic and parasympathetic branches of the autonomic nervous system (ANS). Increased heart rate, due to an increase in sympathetic activity, has been associated with a number of husbandry practices including branding procedures, restraint, transport, and social isolation $(50,56)$ In this study, no significant difference was observed in HR between TTA and C groups over time. However, there was a trend for heart rate to increase atT2 with TTA and to decrease following TT removal. The lack of significant findings may relate to the low number of horses used in this study and the high variation in HR between individuals. In addition, fluctuations in HR are labile and subject to both external and psychological influences (57) and may have been affected by external environmental factors (extreme weather conditions, construction sounds and traffic noise) that occurred on some days but not others. Other studies have used heart rate variability (HRV) as a non-invasive measure of stress in horses $(58,59))$. However, this was not deemed appropriate in this study due to the high prevalence of $2^{\text {nd }}$ degree AV block that was observed. $2^{\text {nd }}$ degree AV block has been shown to significantly influence HRV variables when based on RR intervals (60).

\section{Limitations and future research}

399 Although behaviour offers an immediate means of assessing an animal's response to potential stressors, the 400 interpretation of behaviours is often subjective between assessors. Therefore, future studies may benefit from 401 assessing the inter- and intra-observer reliability of the behaviours measured in this study, and thus reducing 402 limitations due to observer bias. This is particularly important in prey species (including the horse), as outward 403 behavioural signs of fear and distresses may be masked as a means of survival (25). The cortisol assay produced 404 large values for both inter and intra coefficient of variation, consequently limiting the reliability of results. This may have been due to error associated with pipetting or contamination from feed material within the samples.

406 Heart rate measurements showed large variation between individuals in this study and may have been influenced 407 by extraneous factors in some horses. This study was also limited by the small sample size. A larger sample size would reduce the variation among individuals and thus increase reliability of results. 
bioRxiv preprint doi: https://doi.org/10.1101/634717; this version posted May 13,2019. The copyright holder for this preprint (which was not certified by peer review) is the author/funder, who has granted bioRxiv a license to display the preprint in perpetuity. It is made available under aCC-BY 4.0 International license.

409

410

411

412

413

414

415

416

417

418

419

420

421

422

423

424

425

426

427

428

429

430

431

432

433

434

435

436

437

438

439

440

441

442

443

444

445

446

447

448

449

450

451

452

453

\section{Conclusion}

This present study provides novel evidence on the effects of tongue-tie application on stress responses in resting horses, suggesting the application of a TT results in increased agitated/conflict behaviour, decreased desirable relaxed behaviours, and increased salivary cortisol concentration. Further investigation into the appropriate use of TTs in horses should establish whether the costs to the horses, when wearing TT, are offset by the benefits to the horses and other stakeholders. This will enable racing and sport horse regulatory bodies to make informed decisions regarding the continued use of tongue-tie in horses.

\section{Acknowledgments}

The authors would like to thank Kiro Petrovski for the use of the infrared thermographic camera and Sarah Weaver for her assistance with the ELISA assay.

\section{References}

1. Sealy H, Findley J, Franklin S. Reasons the tongue tie is used by South Australian and Western Australian Standardbred and Thoroughbred Trainers. School of Animal and Veterinary Sciences. Roseworthy campus: University of Adelaide; 2014. p. 1-11.

2. Franklin SH, Naylor JRJ, Lane JG. The effect of a tongue-tie in horses with dorsal displacement of the soft palate. Equine Veterinary Journal. 2002;34(S34):430-3.

3. Cornelisse CJ, Holcombe SJ, Derksen FJ, Berney C, Jackson CA. Effect of a tongue-tie on upper airway mechanics in horses during exercise. American journal of veterinary research. 2001;62(5):775.

4. Beard WL, Holcombe SJ, Hinchcliff KW. Effect of a tongue-tie on upper airway mechanics during exercise following sternothyrohyoid myectomy in clinically normal horses. American journal of veterinary research. 2001;62(5):779.

5. Barakzai S, Finnegan C, Boden L. Effect of 'tongue tie' use on racing performance of Thoroughbreds in the United Kingdom. Equine Vet J. 2009;41(8):812-6.

6. Chalmers H, Farberman A, Bermingham A, Sears W, Viel L. The use of a tongue tie alters laryngohyoid position in the standing horse. Equine Vet J. 2013;45(6):711-4.

7. Barakzai SZ, Finnegan C, Dixon PM, Hillyer MH, Boden LA. Use of tongue ties in thoroughbred racehorses in the United Kingdom, and its association with surgery for dorsal displacement of the soft palate. Veterinary Record. 2009;165(10):278.

8. Allen KJ, Christley RM, Birchall MA, Franklin SH. A systematic review of the efficacy of interventions for dynamic intermittent dorsal displacement of the soft palate. Oxford, UK2012. p. 259-66.

9. FEI. FEI General Assembly: on the Vet side 2004 [cited 2016 30.10.16]. Available from: http://inside.fei.org/fei-solr-search/Tongue\%20ties.

10. Thomas H. Tongue injuries: wounds to your horse;s tongue can easily go unnoticed-but that doesnt mean they can be ingnored. EQUUS. 2014:38-46.

11. Findley J, Sealy H, Franklin S. FACTORS ASSOCIATED WITH TONGUE TIE USE IN AUSTRALIAN STANDARDBRED RACEHORSES. Equine Veterinary Journal. 2015(50):18.

12. Pollock P, Perkins J, Kelly P, Reardon R, editors. Longitudinal overground endoscopy findings for conservative management of DDSP. European College of Veterinary Surgeons Annual Scientific Meeting ECV; 2016; Lisbon, Portugal.

13. McGreevy P, Warren-Smith A, Guisard Y. The effect of double bridles and jaw-clamping crank nosebands on temperature of eyes and facial skin of horses. Journal of Veterinary Behavior: Clinical Applications and Research. 2012;7(3):142-8.

14. McGreevy P, McLean A, Buckley P, McConaghy F, McLean C. How riding may affect welfare: What the equine veterinarian needs to know. Equine Veterinary Education. 2011;23(10):531-9. 
bioRxiv preprint doi: https://doi.org/10.1101/634717; this version posted May 13, 2019. The copyright holder for this preprint (which was not certified by peer review) is the author/funder, who has granted bioRxiv a license to display the preprint in perpetuity. It is made available under aCC-BY 4.0 International license.

454 15. Hockenhull J, Creighton E. The use of equipment and training practices and the prevalence of owner-reported ridden behaviour problems in UK leisure horses. Equine Veterinary Journal. 2013;45(1):15-9.

16. Weary DM, Huzzey J, Von Keyserlingk M. BOARD-INVITED REVIEW: Using behavior to predict and identify ill health in animals. J Anim Sci2009. p. 770-7.

459 17. Thorbergson ZW, Nielsen SG, Beaulieu RJ, Doyle RE. Physiological and Behavioral Responses 460 of Horses to Wither Scratching and Patting the Neck When Under Saddle. Journal of Applied Animal 461 Welfare Science. 2016;19(3):245-59.

462 18. Pierard M, Hall C, König Von Borstel U, Averis A, Hawson L, McLean A, et al. Evolving 463 protocols for research in equitation science. Journal of Veterinary Behavior: Clinical Applications and 464 Research. 2015;10(3):255-66.

465 19. Visser EK, van Reenen CG, van Der Werf JTN, Schilder MBH, Knaap JH, Barneveld A, et al. 466 Heart rate and heart rate variability during a novel object test and a handling test in young horses. 467 Physiology \& Behavior. 2002;76(2):289-96.

468 20. Schmidt A, Aurich J, Möstl E, Müller J, Aurich C. Changes in cortisol release and heart rate and 469 heart rate variability during the initial training of 3-year-old sport horses. Hormones and Behavior. 470 2010;58(4):628-36.

471 21. Peeters M, Sulon J, Serteyn D, Vandenheede M. Assessment of stress level in horses during competition using salivary cortisol: preliminary studies. 2010. p. 216-.

22. Valera M, Bartolomé E, Sánchez MJ, Molina A, Cook N, Schaefer A. Changes in Eye Temperature and Stress Assessment in Horses During Show Jumping Competitions. Journal of Equine Veterinary Science. 2012;32(12):827-30.

23. Fenner K, Yoon S, White P, Starling M, McGreevy P, Munderloh UG. The Effect of Noseband Tightening on Horses' Behavior, Eye Temperature, and Cardiac Responses. PLoS ONE. 2016;11(5). 24. Bartolomé E, Sánchez MJ, Molina A, Schaefer AL, Cervantes I, Valera M. Using eye temperature and heart rate for stress assessment in young horses competing in jumping competitions and its possible influence on sport performance. 2013;7(12):2044-53.

25. Yarnell K, Hall C, Billett E. An assessment of the aversive nature of an animal management procedure (clipping) using behavioral and physiological measures. Physiology \& Behavior. 2013;118:32-9.

26. Rietmann TR, Stauffacher M, Bernasconi P, Auer JA, Weishaupt MA. The Association between Heart Rate, Heart Rate Variability, Endocrine and Behavioural Pain Measures in Horses Suffering from Laminitis*. Journal of Veterinary Medicine Series A. 2004;51(5):218-25.

27. Piccione G, Bazzano M, Giannetto C, Panzera M, Fazio F. Evaluation of Heart Rate as Marker of Stress during Road Transport in Horses. Acta Sci Vet. 2013;41.

28. Australian code for the care and use of animals for scientific purposes, (2013).

29. McGreevy PD, S F. Over 20\% of Australian horses race with their tongues tied to their lower jaw: The Conversation; 2018 [cited 2019 11/04/2019]. Available from:

https://theconversation.com/over-20-of-australian-horses-race-with-their-tongues-tied-to-theirlower-jaw-99584.

30. Young T, Creighton E, Smith T, Hosie C. A novel scale of behavioural indicators of stress for use with domestic horses. Applied Animal Behaviour Science. 2012;140(1-2):33-43.

31. Górecka-Bruzda A, Kosińska I, Jaworski Z, Jezierski T, Murphy J. Conflict behavior in elite show jumping and dressage horses. Journal of Veterinary Behavior: Clinical Applications and Research. 2015;10(2):137-46.

32. McGreevy P, McLean A, Warren-Smith A, Waran N, Goodwin D, editors. Defining the terms and processes associated with equitation. Proceedings of the 1st International Equitation Science Symposium; 2005; Sydney: University Press Melbourne, Australia.

33. Fraser AF. The behaviour and welfare of the horse. 2nd ed. ed. Fraser A, editor. Wallingford, Oxfordshire: CABI pub.; 2010.

34. Christensen JW, Rundgren M, Olsson K. Training methods for horses: habituation to a frightening stimulus. Equine Veterinary Journal. 2006;38(5):439-43. 
bioRxiv preprint doi: https://doi.org/10.1101/634717; this version posted May 13, 2019. The copyright holder for this preprint (which was not certified by peer review) is the author/funder, who has granted bioRxiv a license to display the preprint in perpetuity. It is made available under aCC-BY 4.0 International license.

506 35. Dalla Costa E, Minero M, Canali E, Lebelt D, Stucke D, Leach MC. Development of the Horse

507

508

509

510 Grimace Scale (HGS) as a pain assessment tool in horses undergoing routine castration. PLoS ONE. 2014;9(3).

511 37. Waring GH. Horse Behaviour (2nd ed.)

512 2nd ed. Norwich, UK: Noyes Publications/William Andrews Publishing; 2003. 181-2 p.

513 38. von Borstel UU, Duncan IJH, Shoveller AK, Merkies K, Keeling LJ, Millman ST. Impact of riding

514 in a coercively obtained Rollkur posture on welfare and fear of performance horses. Applied Animal

515 Behaviour Science. 2009;116(2):228-36.

516 39. Gaynor JS. Handbook of Veterinary Pain Management. 3rd ed. ed. Muir WW, III, editor.

517 London: Elsevier Health Sciences; 2014.

518 40. Smiet E, Van Dierendonck MC, Sleutjens J, Menheere PPCA, van Breda E, de Boer D, et al.

519 Effect of different head and neck positions on behaviour, heart rate variability and cortisol levels in

520 lunged Royal Dutch Sport horses. The Veterinary Journal. 2014;202(1):26-32.

521 41. Stafford KJ. Horse reactions to human attitudes and behavior. Anthrozoos: A

522 Multidisciplinary Journal of The Interactions of People \&\#38. 2002;15(4):323-31.

523 42. Gleerup KB, Forkman B, Lindegaard C, Andersen PH. An equine pain face. Veterinary

524 Anaesthesia and Analgesia. 2015;42(1):103-14.

525 43. McLean AN, McGreevy PD. Horse-training techniques that may defy the principles of learning

526 theory and compromise welfare. Journal of Veterinary Behavior: Clinical Applications and Research.

527 2010;5(4):187-95.

528 44. Freire R, Buckley P, Cooper JJ. Effects of different forms of exercise on post inhibitory

529 rebound and unwanted behaviour in stabled horses. Equine Veterinary Journal. 2009;41(5):487-92.

530 45. Yeon SC. The Effect of Exercise Deprivation on the Behaviour and Physiology of Straight Stall

531 Confined Pregnant Mares. Animal Welfare. 2001;10(3):257-67.

532 46. Vestergaard K. Dust-bathing in the domestic fowl - diurnal rhythm and dust deprivation.

533 Dust-bathing in the domestic fowl - diurnal rhythm and dust deprivation. 1982(5):487-95.

534 47. Muir W. Trauma: physiology, pathophysiology, and clinical implications. Journal of Veterinary 535 Emergency and Critical Care. 2006;16(4):253-63.

536 48. Beerda B, Schilder MBH, Janssen NSCRM, Mol JA. The Use of Saliva Cortisol, Urinary Cortisol, 537 and Catecholamine Measurements for a Noninvasive Assessment of Stress Responses in Dogs.

538 Hormones and Behavior. 1996;30(3):272-9.

539 49. Strzelec K, Pietrzak S, Kankofer M. Cortisol concentration in the saliva of horses subjected to 540 different kinds of exercise. Acta Veterinaria Brno. 2011;80(1):101-5.

541 50. Schmidt A, Möstl E, Wehnert C, Aurich J, Müller J, Aurich C. Cortisol release and heart rate

542 variability in horses during road transport. Hormones and Behavior. 2010;57(2):209-15.

543 51. Pell SM, McGreevy PD. A study of cortisol and beta-endorphin levels in stereotypic and

544 normal Thoroughbreds. Applied Animal Behaviour Science. 1999;64(2):81-90.

545 52. Christensen JW, Ladewig J, Søndergaard E, Malmkvist J. Effects of individual versus group

546 stabling on social behaviour in domestic stallions. Applied Animal Behaviour Science. 2002;75(3):233-

547

548

549 48.

53. Peeters M, Sulon J, Beckers JF, Ledoux D, Vandenheede M. Comparison between blood serum and salivary cortisol concentrations in horses using an adrenocorticotropic hormone challenge. Equine veterinary journal. 2011;43(4):487.

54. McManus C, Tanure CB, Peripolli V, Seixas L, Fischer V, Gabbi AM, et al. Infrared thermography in animal production: An overview. Computers and Electronics in Agriculture. 2016;123:10-6.

55. Dai F, Cogi NH, Heinzl EUL, Dalla Costa E, Canali E, Minero M. Validation of a fear test in sport horses using infrared thermography. Journal of Veterinary Behavior: Clinical Applications and Research. 2015;10(2):128-36.

56. Bachman A, Thompson DL, Walker NL, Southerland CV. Hormonal and heart rate responses to a surprise stimulus and isolation stress in horses. Journal of Equine Veterinary Science.

559 2017;52:61-. 
bioRxiv preprint doi: https://doi.org/10.1101/634717- this version posted May 13, 2019. The copyright holder for this preprint (which was not certified by peer review) is the author/funder, who has granted bioRxiv a license to display the preprint in perpetuity. It is made available under aCC-BY 4.0 International license.

560 57. Buuse M, Acker SABE, Fluttert M, Kloet ER. Blood pressure, heart rate, and behavioral

561 responses to psychological "novelty" stress in freely moving rats. Oxford, UK2001. p. 490-9.

56258 . Stucke D, Große Ruse M, Lebelt D. Measuring heart rate variability in horses to investigate

563 the autonomic nervous system activity - Pros and cons of different methods. Applied Animal

564 Behaviour Science. 2015;166(1):1-10.

565 59. Gehrke EK, Baldwin A, Schiltz PM. Heart Rate Variability in Horses Engaged in Equine-Assisted 566 Activities. Journal of Equine Veterinary Science. 2011;31(2):78-84.

567 60. Eggensperger, BH., Schwarzwald., CC. Influence of $2^{\text {nd }}$ degree AV blocks, ECG recording length 568 and recording time on heart rate variability analyses in horses. Journal of Veterinary Cardiology.

569 2017; 19: 160-174.

570 